\title{
EVALUATION OF NANOCOBALT PARTICLES ADDITION IN RUMINANT RATIONS BY IN VITRO GAS PRODUCTION
}

\author{
Etab R.I. Abd El-Galil* and N.E.Y. El-Bordeny \\ Animal Production Department, Faculty of Agriculture, Ain Shams University, Cairo, Egypt. \\ *aetab@live.com
}

(Received 15/11/2017, accepted 4/3/2018)

\section{SUMMARY}

\begin{abstract}
$\mathrm{T}$ The objectives of this paper are to evaluate the addition of nanocobalt on growth of cellulolytic bacteria, degradability of dry matter, cellulose and hemicellulose regarding In vitro gas production. The different levels of nanocobalt as addition element on fermentation kinetics were 0 , $25,50,75,100$ and $125 \%$ from requirements of animal in ration as dry matter base. Cellulolytic bacteria had been isolated :Cellulomonas cellulasea, Acetobacter xylinum, Thermonospora fusca, Ruminococcus albus , Bacillus sp., Clostridium cellulovorans and Selenomonas ruminantium. Standard ration (1:1 concentrate :clover hay ) was incubated for 48 hours. The results indicated that the values of DMD , Hemi.D and Cellul.D, which nanocobalt addition were higher when levels were 50 and $75 \%$ compared control. Total cellulolytic bacteria counts in rumen content were higher $(\mathrm{P}<0.05)$ in cobalt $100 \%$ (11.30) and nanocobalt 75,100 and $125 \%(11.73,12.72$ and 12.20$)$, respectively, while lower value was in nanocobalt $25 \%(9.72)$ compared control (7.58). Results revealed that added nanocobalt affect on growth of cellulolytic bacteria and increase degradability of cellulose. The nanocobalt additives had no effect on ruminal $\mathrm{pH}$ but more effect on ruminal ammonia and TVF's values, as well as degradability of cell wall constituents and microbial protein production. The extent of gas production was high in control ration, adding cobalt (100\%) and nanocobalt $(50 \%)$ than other adding levels. Microbial protein (M P) and efficiency microbial protein ( EM P) recorded higher values in all different $(25,50,75,100$ and $125 \%)$ added of nanocobalt compared to control (0\%). Gas production degradability after 48 hours incubation hemicellulose of $25 \%$ nanocobalt recorded the highest value (2444.69 ) compared to any adding nanocobalt levels and control, while degradability for cellulose recorded higher values for $50 \%$ nanocobalt compared to other levels and control. It concluded that adding nanocobalt improved gas production, growth of cellulolytic bacteria ,ammonia ,total volatile fatty acids, metabolisable energy and cell wall constituents degradability.
\end{abstract}

Keywords: cellulolytic bacteria, In vitro gas production, dry matter, cellulose, hemicellulose, degradability.

\section{INTRODUCTION}

The ruminal microflora can synthesize vitamin B12, provided dietary cobalt is available in sufficient quantities. Consequently, the vitamin B12 requirement of these animals can be covered by dietary cobalt. But for a potential replacement of cobalt by vitamin B12, there are not enough data to evaluate the consequences on health and performance for these species under field conditions. Supplementation of cobalt from the diet would also affect ruminal microflora, its composition and function. Some small beneficial effects observed in ruminants after cobalt supply are likely to be related to an unspecific cobalt effect on the microflora rather than to vitamin B12. An optimal micronutrient supply of ruminants would therefore include cobalt ( Sutton and Elliot,1972).

Adding supplemental cobalt to a high-concentrate diet formulated to be deficient in cobalt increased ruminal propionate production in beef steers (Tiffany et al., 2006). Gall et al. (1949) suggested that the digestibility of a diet decreases through bacterial changes when Cobalt is deficient. Scholljegerdes et al. (2010) found that dietary cobalt increased forage intake in lambs although the mechanism of action is not clear. The increase in intake may have been due to improvements in ruminal fermentation related to alterations in the ruminal microbial population, specifically the cellulolytic bacteria, which appear to be 
most sensitive to additional cobalt. Therefore, a site and extent of digestion and growth performance trial is warranted to more completely evaluate the impact of supranutritional levels of cobalt in growing lambs.

The rate and extent of DM fermentation in the rumen are very important determinants for the nutrients absorbed by ruminants. Menke and Steingass (1988) developed the In vitro gas production technique to evaluate the nutritive value of forages and to estimate the rate and extent of DM degradation indirectly using the gas production during fermentation. In vitro gas production technique is well indicated with animal performance (Orskov, 1989), food intake (Blummel and Orskov, 1993), microbial protein synthesis (Krishnamoorthy et al. (1991) and Krishnamoorthy et al. (2005) and In vivo digestibility (Khazaal et al. 1993). Considering the advantages of gas production technique with its simplicity of use and the possibility of processing a large number of samples in a short time it will be important to find significant (Valentin et al., 1999). Many researchers have investigated fermentation kinetics obtained by In vitro gas production technique (Cone et al., 1998, 1999 and 2002).

Bunglavan et al. (2014) Nanotechnology can be applied in the production of nanoparticles which can be used in improving the digestion and absorption in livestock both as novel food ingredients or additives and for improving food safety and quality control. Nanotechnology is in constant development and its applications are ever more varied and specific, with a high potential for improving livestock production and animals in general. The study of nanotechnology in these areas is still very limited. Nanoparticles incorporation in animal nutrition studies which can greatly enhance the efficiency of growth and production of livestock should be conducted at a lower risk to consumers. However, a great amount of research is still required to support the effectiveness, and mainly the safety of nanotechnology, avoiding any harm to the livestock, environment and to human beings.

So, the aim of this study was to determine effect of using nanocobalt with different levels as addition element on fermentation kinetics of standard ration using In vitro gas production technique and evaluate the effect on rumen parameters and fibrolytic rumen bacteria .

\section{MATERIALS AND METHODS}

\section{In vitro gas production technique}

Two days before beginning of the experiment, $400 \pm 4 \mathrm{mg}$ of sample for each level (contained clover hay as a roughage and concentrate at ratio of 50:50) was weighed into $125 \mathrm{~mL}$ glass bottles. A buffer solution was prepared before addition of rumen fluid as described by Szumacher-Strabel et al. (2002) and flushed continuously with $\mathrm{CO}_{2}$ at $39{ }^{\circ} \mathrm{C}$ during sample inoculation. Rumen fluid was obtained from slaughter house and it was collected from buffalo. The collected rumen fluid was mixed into a bottle (1L) with an $\mathrm{O}_{2}$-free headspace and immediately transported to laboratory at $39^{\circ} \mathrm{C}$. Upon arrival at the laboratory, the rumen fluid was filtered through four layers of cheesecloth to eliminate large feed particles. The buffer solution was added to rumen fluid at ratio 4:1 and forty $\mathrm{mL}$ of this inoculum was added to each bottle, then the headspace of each bottle was flushed with $\mathrm{CO}_{2}$, and closed. The initial $\mathrm{pH}$ of the inoculums was from 6.8 to 6.9. Triplicates of each sample were used in two separate runs .

\section{Degradability}

Dry matter degradability (\% dDM) was calculated as the difference between the sample DM content and that in the residual after $48 \mathrm{~h}$ incubation / sample DM content * 100. NDF and ADF of the residuals after fermentation were analyzed with the same methods used for feed ingredients analysis. Degradability of NDF, ADF, cellulose and hemicellulose were calculated as difference between the content in the sample before and after incubation / content in the sample before incubation $* 100$.

\section{Total gas production}

After $48 \mathrm{~h}$ of samples incubation, the total gas production (GP) was estimated by the displacement of syringe piston, which was connected to the serum flasks. The gas produced due to fermentation of substrate was calculated by subtracting gas produced in blank vessels (without substrate) from total gas produced in the vessels containing buffered rumen fluid and substrate.

\section{Calculation}

Metabolizable energy (ME, Mcal/kg DM), In vitro organic matter digestibility (OMD, g/kg OM) were estimated according to (Menke and Steingass, 1988), short chain fatty acid (SCFA)concentrations 
were calculated according to Getachew et al.(2002), microbial biomass production (MCP) and efficiency of microbial biomass production (EMP) were calculated according to Blummel et al. (1997) as:

- $\quad \mathrm{ME}(\mathrm{mJ} / \mathrm{kg} \mathrm{DM})=2.20+0.136 \mathrm{GP}+0.057 \mathrm{CP}(\%)$.

- $\quad \mathrm{OMD}=14.88+0.889 \mathrm{GP}+4.5 \mathrm{CP}(\%)+0.0651$ ash $(\%)$.

- $\quad \operatorname{SCFA}(\mathrm{mmol} / 200 \mathrm{mg} \mathrm{DM})=-0.00425+0.0222 * \mathrm{GP}$

- $\quad \mathrm{MCP}(\mathrm{mg} / \mathrm{g} \mathrm{DM})=\mathrm{mg} \mathrm{dDM}-\mathrm{GP} * 2.2$.

- $\quad \mathrm{EMP}=(\mathrm{mg} \mathrm{dDM}-\mathrm{GP} * 2.2)) / \mathrm{mg} \mathrm{DMD}$.

where : GP is net gas production in $\mathrm{mL}$ from $200 \mathrm{mg}$ of dry sample after $24 \mathrm{~h}$ of incubation, $2.2 \mathrm{mg} / \mathrm{mL}$ is a stoichiometric factor that expresses $\mathrm{mg}$ of $\mathrm{C}, \mathrm{H}$, and $\mathrm{O}$ required for the SCFA gas associated with production of $1 \mathrm{~mL}$ of gas.

After $48 \mathrm{hrs}$ of incubation, the filtrated rumen liquor for each sample was subjected for further investigation. The $\mathrm{pH}$ of rumen fluid was measured by $\mathrm{pH}$ meter and quantitative analysis of ammonia concentration was carried out by Nesler method modified by Szumacher-Strabel et al.(2002) and total volatile fatty acids (TVFA's) was analyzed according to Barnett and Reid, (1956).

\section{Chemical analysis of feed ingredients}

Ration ingredients were analyzed for $\mathrm{DM}$ and ash, Crude fiber $(\mathrm{CF})$, Crude protein $(\mathrm{CP}=\mathrm{Nitrogen} \% \mathrm{x}$ 6.25) and ether extract (EE) contents according to AOAC (1997). Neutral detergent fiber (NDF), acid detergent fiber (ADF) and acid detergent lignin (ADL) contents were analyzed sequentially (Van Soest et al., 1991) using the Ankom ${ }^{200}$ Fibre Analyzer for NDF and ADF and thereafter soaking the residual with $72 \%$ sulfuric acid for 3 hours. The NDF content was analyzed with 2 additions of heat-stable $\alpha$-amylase and 1:1 g sodium sulfite per gm sample in the neutral detergent solution (Hansen et al., 2016). NDF and ADF are expressed inclusive of residual ash and hemicellulose and cellulose calculated from NDF, ADF and ADL values. The nitrogen free extract (NFE) was obtained by the difference.

\section{Preparation of bacterial cultures}

Seven strains of cellulolytic bacteria were isolated from rumen fluid of In vitro gas production and were grown as pure cultural. The separated strains were Cellulomonas cellulasea , Acetobacter xylinum , Thermonospora fusca , Ruminococcus albus, Bacillus sp. , Clostridium cellulovorans and Selenomonas ruminantium. The isolation of species used the pour-plate technique for pure preparation of cultures according to A.T.C.C. (1992). The rumen samples were immediately gassed with $\mathrm{CO}_{2}$ and viable counts of rumen cellulolytic bacteria were determined according to the method described by Moir (1951) and Gall et al.(1945) and their classification were done according to Pounden and Hibs (1948) and Sleat et al.(1984).

\section{Standard ration and nanocobalt addition}

Six levels of nanocobalt were tested in a standard ration. The nanocobalt levels $0,25,50,75,100$ and $125 \%$ of small ruminants (sheep and goats) according to NRC (1985) requirements ( $0.2 \mathrm{mg} / \mathrm{kg}$ DM intake $=100 \%)$ and $100 \%$ cobalt supplemented ration as standared level. The six levels were diluted in $100 \mathrm{ml}$ distilled water each, then used to added to the tested glass vessels. The tested ration consisted of a concentrate mixture (corn grain, wheat bran, soybean meal, salt and limestone) and Egyptian clover hay. The ration was prepared using 1:1 (w/w) roughage to concentrate ratio. The chemical composition of feedstuffs are shown in Table (1).

\section{Nanocobalt characterization}

Cobalt oxide nanoparticles were successfully prepared by thermal decomposition of cobalt hydroxide synthesized from cobalt acetate, ammonium hydroxide and $10 \%$ glycerol according to Manigandan et al. (2013) . X ray determined (XRD )patterns of the cobalt oxide nanoparticles calcined at $450{ }^{\circ} \mathrm{C}$, indicates the cobalt oxide has cubic phase structure. The average grain size of cobalt oxide is determined using Scherrer relation, and it was found to be around $49 \mathrm{~nm}$. It can be seen that the particles adopt irregular morphology with different sized particle. In addition, cobalt oxide nanoparticles show rod shape with smooth surface. It clearly indicates the fine rod like particles adsorbed on the surface due to the aggregation. It shows the rod like agglomerates were purely due to the magnetic induction between the particles (Koutzarova et al.,2006 ).

\section{Statistical analysis}


The data of In vitro gas production, dry matter, organic matter, hemicellulose, cellulose digestibility, and In vitro dry matter, organic matter, hemicellulose and cellulose degradability were statistically analyzed according to statistical analysis system User's Guide, (SAS, 1998). Separation among means was carried out by using Duncan Multiple test (Duncan, 1955). The following model was used:

$\mathrm{Y}_{\mathrm{ij}}=\mu+\mathrm{S}_{\mathrm{i}}+\alpha_{\mathrm{ij}}$

Where: $\mathrm{Y}$ ij = the observation of the model, $\mu=$ General mean common element to all observation, $\mathrm{Si}=$ the effect of the treatment $(\mathrm{i}=1 \ldots 6)$, and $\alpha \mathrm{ij}=$ the effect of experimental error.

Table (1) : Chemical composition and cell wall constitutes of clover, concentrate and standard ration.

\begin{tabular}{lccc}
\hline Item & Clover hay & Concentrate $^{*}$ & Standard ration \\
\hline Dry matter & 92.40 & 87.05 & 89.73 \\
Chemical analysis (\%) on DM basis & & & \\
\hline Organic matter & 86.79 & 94.73 & 90.76 \\
Crud protien & 17.41 & 16.19 & 16.80 \\
Ether extract & 3.98 & 4.77 & 4.38 \\
Crud fiber & 40.94 & 20.67 & 30.80 \\
Nitrogen free extract & 24.46 & 53.10 & 38.78 \\
Ash & 13.21 & 5.27 & 9.24 \\
Cell wall constitutes (\%) & & \\
NDF & 40.94 & 53.94 & 47.44 \\
ADF & 26.88 & 20.66 & 23.77 \\
ADL & 5.80 & 1.41 & 3.61 \\
Hemicell. & 14.06 & 33.28 & 23.67 \\
Cellulose & 21.08 & 19.25 & 20.16 \\
Minerals content & & & \\
Ca $\%$ DM & 4.21 & 0.68 & 2.44 \\
Mg,\% DM & 0.64 & 0.29 & 0.47 \\
P ,\% DM & 0.37 & 0.60 & 0.48 \\
K,\% DM & 3.46 & 3.27 & 3.37 \\
Na,\% DM & 0.63 & 0.43 & 0.52 \\
Mn, (mg/kg DM) & 67.00 & 21.52 & 44.26 \\
Cu,(mg/kg DM) & 7.00 & 2.33 & 4.66 \\
Zn ,(mg/kg DM) & 11.00 & 17.53 & 14.26 \\
Fe, (mg/kg DM) & 3138 & 190.66 & 0.13 \\
Co, (mg/kg DM) & 0.26 & - & 53 \\
\hline consists of: 55.9\%Com & & \\
\hline
\end{tabular}

*consists of: $55.9 \%$ Corn grain, $22 \%$ Soybean meal, , $20.3 \%$ Wheat bran ,0.8 \% salt ( $\mathrm{Na} \mathrm{cl} \mathrm{),1 \%} \mathrm{lime} \mathrm{stone.}$

\section{RESULTS AND DISCUSSION}

\section{DM, OM, Cellulose and Hemicellulose degradability}

Within treatments, a significant increase $(\mathrm{P}<0.05)$ in DM degradability after 48 hours was recorded for rations supplemented with nanocobalt (50 and 75\%). The highest DM degradability was recorded for ration supplemented with normal $100 \%$ of cobalt requirement (Table 2). The present results pointed to significant negative effect for cobalt nanoparticles supplementation (75, 100 and $125 \%$ ) on OM degradability. In the contrary Partha Sarathi Swain et al.(2015) reported that minerals nanoparticles are having a great potential as mineral feed supplements in animals even at very lower doses than the conventional organic and inorganic sources. However, the systematic and thorough studies are to be undertaken to see the toxic effects if any after feeding animals for prolong period. Moreover, these synthesized mineral nanoparticles should be fed to a large number of animals to standardize both the positive and adverse effects before incorporating in the ration on a regular basis.

While the levels of cobalt nanoparticles above $50 \%$ of cobalt requirements resulted in significant $(\mathrm{P}<0.05)$ decrease in OM degradability (Table 2). On the other hand the cobalt nanoparticles supplementation had no significant effect on NDF, ADF and hemicellulose degradability after 48 hours, except $100 \%$ level for NDF and ADF degradation. Moreover cobalt nanoparticles supplementation 
recorded higher cellulose degradation compared to non supplemented ration ( $0 \%$ level) and the ration supplemented with cobalt oxide(100\%). This positive response for cobalt nanoparticles supplementation on NDF, ADF and hemicellulose degradability may be attributed to that cobalt nanoparticles resulted in increase total cellulolytic bacteria counts (Table 3) consequently increase cellulolytic enzyme activity. In this connection Elghandour et al., (2014) reported an improved fibers fractions degradability as a result of increased cellulolytic digester species : Fibrobacter succinogenes, Ruminococcus flavifaciens and Selenomonas ruminantium. Also Colombatto et al., (2007) stated that fibrolytic enzymes enhanced the fermentation of cellulose and xylan by a combination of pre- and post- incubation effects.

Table (2): Degradibility of DM, OM, Cellulose and Hemicellulose after 48 hours on DM basis.

\begin{tabular}{|c|c|c|c|c|c|c|c|c|}
\hline \multirow{2}{*}{ Item } & \multirow{2}{*}{$\begin{array}{c}\text { Normal } \\
100 \\
\end{array}$} & \multicolumn{6}{|c|}{ Nanocobalt , $\%$} & \multirow{2}{*}{$\begin{array}{c}\text { SE } \\
\pm\end{array}$} \\
\hline & & 0 & 25 & 50 & 75 & 100 & 125 & \\
\hline $\mathrm{DMD}, \%$ & 74.63 & $70.31^{\mathrm{c}}$ & $69.96^{\mathrm{d}}$ & $72.78^{\mathrm{a}}$ & $71.75^{\mathrm{b}}$ & $64.40^{\mathrm{e}}$ & $70.84^{\mathrm{c}}$ & 0.70 \\
\hline OMD, $\%$ & 41.26 & $41.78^{a}$ & $40.07^{\mathrm{a}}$ & $40.16^{\mathrm{a}}$ & $38.22^{c}$ & $37.12^{d}$ & $39.48^{b}$ & 0.27 \\
\hline NDFD, $\%$ & 50.60 & $39.84^{\mathrm{d}}$ & $40.76^{\mathrm{c}}$ & $44.84^{\mathrm{b}}$ & $45.62^{\mathrm{b}}$ & $50.54^{\mathrm{a}}$ & $51.33^{\mathrm{a}}$ & 0.95 \\
\hline $\mathrm{ADFD}, \%$ & 45.73 & $32.29^{f}$ & $37.38^{\mathrm{e}}$ & $42.88^{\mathrm{c}}$ & $39.38^{d}$ & $59.46^{\mathrm{a}}$ & $57.37^{\mathrm{b}}$ & 1.65 \\
\hline Hemi.D, \% & 55.96 & $48.19^{b}$ & $44.45^{\mathrm{c}}$ & $47.01^{\mathrm{b}}$ & $52.50^{\mathrm{a}}$ & $40.50^{\mathrm{d}}$ & $44.70^{c}$ & 0.99 \\
\hline Cellul.D, $\%$ & 40.05 & $42.91^{\mathrm{e}}$ & $55.36^{\mathrm{c}}$ & $54.05^{\mathrm{d}}$ & $56.72^{\mathrm{c}}$ & $61.37^{\mathrm{a}}$ & $59.72^{b}$ & 3.21 \\
\hline
\end{tabular}

\section{Cellulolytic bacteria}

The data showed a significant increase $(\mathrm{P}<0.05)$ in total cellulolytic bacteria counts as cobalt nanoparticles levels of the nutrient requirement compared to $0 \%$ (Table 3). The same trend was observed with Cellulomonas, Bacillus, Thermonospora, Acetobacter, Ruminococcus, Clostridium and Selenomonas. Increasing nano cobalt above $100 \%$ of the requirement did not affect the total bacteria count and the different strains, except Selenomonas. Nano cobalt supplementation with 100 and $125 \%$ of the requirement recorded the highest total cellulolytic bacteria counts and all bacteria strains compared to the other levels (Table 3). These results may be due to ration supplementation with cobalt nanoparticles,

Table( 3): Count of cellulolytic bacteria in rumen fluid (No. of bacteria $x 10^{7} / \mathrm{ml}$ rumen liquor).

\begin{tabular}{|c|c|c|c|c|c|c|c|c|}
\hline \multirow{2}{*}{ Item } & \multirow{2}{*}{$\begin{array}{l}\text { Normal } \\
100\end{array}$} & \multicolumn{6}{|c|}{ Nanocobalt ,\% } & \multirow{2}{*}{$\begin{array}{c}\text { SE } \\
\pm\end{array}$} \\
\hline & & 0 & 25 & 50 & 75 & 100 & 125 & \\
\hline Total count & 11.30 & $7.58^{\mathrm{e}}$ & $9.72^{\mathrm{d}}$ & $10.94^{\mathrm{c}}$ & $11.73^{b}$ & $12.72^{\mathrm{a}}$ & $12.20^{\mathrm{a}}$ & 2.10 \\
\hline Cellulomonas & 2.39 & $1.84^{\mathrm{d}}$ & $1.87^{\mathrm{d}}$ & $2.07^{\mathrm{c}}$ & $2.38^{\mathrm{b}}$ & $2.64^{\mathrm{a}}$ & $2.75^{\mathrm{a}}$ & 0.07 \\
\hline$\%$ & 21.11 & 24.27 & 19.24 & 18.92 & 20.29 & 20.75 & 22.54 & \\
\hline Bacillus & 0.32 & $0.18^{\mathrm{d}}$ & $0.24^{\mathrm{c}}$ & $0.26^{\mathrm{b}}$ & $0.28^{\mathrm{b}}$ & $0.33^{\mathrm{a}}$ & $0.31^{\mathrm{a}}$ & 0.08 \\
\hline$\%$ & 2.83 & 2.37 & 2.47 & 2.37 & 2.39 & 2.59 & 2.54 & \\
\hline Thermonospora & 0.62 & $0.50^{c}$ & $0.57^{\mathrm{c}}$ & $0.61^{\mathrm{b}}$ & $0.64^{\mathrm{b}}$ & $0.66^{\mathrm{a}}$ & $0.69^{\mathrm{a}}$ & 0.06 \\
\hline$\%$ & 5.48 & 6.59 & 5.86 & 5.57 & 5.45 & 5.19 & 5.65 & \\
\hline Acetobacter & 1.50 & $1.22^{\mathrm{e}}$ & $1.32^{\mathrm{d}}$ & $1.53^{\mathrm{b}}$ & $1.62^{b}$ & $1.77^{\mathrm{a}}$ & $1.73^{\mathrm{a}}$ & 0.16 \\
\hline$\%$ & 13.27 & 16.09 & 13.58 & 13.98 & 13.81 & 13.91 & 14.18 & \\
\hline Ruminococcus & 2.46 & $1.07^{\mathrm{e}}$ & $2.08^{\mathrm{d}}$ & $2.46^{\mathrm{c}}$ & $2.66^{\mathrm{b}}$ & $2.73^{a}$ & $2.83^{\mathrm{a}}$ & 0.18 \\
\hline$\%$ & 21.77 & 14.11 & 21.39 & 22.38 & 22.67 & 21.46 & 23.19 & \\
\hline Clostridium & 0.93 & $0.92^{c}$ & $0.96^{\mathrm{c}}$ & $1.17^{\mathrm{b}}$ & $1.22^{b}$ & $1.35^{\mathrm{a}}$ & $1.44^{\mathrm{a}}$ & 0.12 \\
\hline$\%$ & 8.23 & 12.14 & 9.87 & 10.69 & 10.40 & 10.61 & 11.80 & \\
\hline Seleno.rumina & 3.08 & $0.85^{\mathrm{d}}$ & $2.68^{c}$ & $2.84^{\mathrm{b}}$ & $2.93^{\mathrm{b}}$ & $3.24^{\mathrm{a}}$ & $2.45^{\mathrm{c}}$ & 0.21 \\
\hline$\%$ & 27.25 & 11.12 & 27.57 & 25.96 & 24.98 & 25.47 & 20.08 & \\
\hline
\end{tabular}


enhance and stimulate activity of cellulolytic bacteria in rumen. These results clarify increasing values of NDF, ADF, hemicellulose and cellulose degradability. In this connection Scholljegerdes et al.,(2010) reported that dietary Co improve ruminal fermentation related to alterations in the ruminal microbial population, specifically the cellulolytic bacteria, which appear to be most sensitive to cobalt supplementation.

Supplementing a forage-based diet with Co may be useful due to the higher ruminal vit B12 production observed with high-forage diets (50 forage : 50 concentrate ratio) compared to a relatively higher concentrate (40:60) diets (Sutton and Elliot, 1972). Adding supplementaion Co to a highconcentrate diet formulated to be deficient in Co increased ruminal propionate production in beef steers (Tiffany et al., 2002). Clostridium cellulovorans degrades native substrates efficiently by producing an extracellular enzyme complex (Roger et al., 2005). Colombatto et al. (2007) stated that fibrolytic enzymes enhanced the fermentation of cellulose and xylan by a combination of pre- and post-incubation effects. In relation to these results, Weiner et al.,(1994) reported that the Ruminococcus albus, Ruminococcus flavefaciens, and Fibrobacter succinogenes bacteria generally are regarded as the predominant cellulolytic microbes in the rumen. And it was able to utilize cellulose or in some cases xylan and its hydrolytic products as their nearly sole energy sources for growth. Although a large number of microorganisms are capable of degrading cellulose, only few of these microorganisms produce significant quantities of cell-free enzymes capable of completely hydrolyzing crystalline cellulose (In vitro studies). A majority of cellulolytic clostridia reported present of several xylanases that have been cloned and characterized (Hayashi et al., 1999 and Mohand-Oussaid et al., 1999).

\section{Fermentation parameters}

Supplementing the experimental ration with ascending level of cobalt nanoparticles had no significant effect on $\mathrm{pH}$ value and metabolizable energy ME (Mcal/g) (Table 4). A significant increase in ammonia concentration $(\mathrm{mg} / 100 \mathrm{ml})$ and total volatile fatty acids (meq $/ 100 \mathrm{ml})$ were recorded $(\mathrm{P}>0.05)$ as a result to supplementing ration with cobalt nanoparticles at 25,50 and $75 \%$ of Co requirement compared to other levels. These results may be due to added nanocobalt affect on bacteria activity which increased growth and activity ruminal bacteria and causes increase protein degradation (Table 3). Ruminant ration supplemented with cobalt nanoparticles resulted in increase microbial mass protein (MP) and efficiency of microbial mass (EMP) compared to the control ( $0 \%$ supplemented) and the ration supplemented with cobalt oxide $100 \%$ of requirements. Ruminal $\mathrm{pH}$ was not affected during fermentation processes in the experiment. Several studies have suggested that during fermentation due to increasing $\mathrm{pH}$ and lactate utilization making $\mathrm{pH}$ relatively more stable and meet the needs of rumen microbes to perform its activity

Table(4): Gas value (kinetics of gas production in ration $\mathrm{ml} / 400 \mathrm{mg} \mathrm{DM}$ ) and rumen fermentation

\begin{tabular}{|c|c|c|c|c|c|c|c|c|}
\hline \multirow{2}{*}{ Item } & \multirow{2}{*}{$\begin{array}{l}\text { Normal } \\
100 \\
\end{array}$} & \multicolumn{6}{|c|}{ Nanocobalt , $\%$} & \multirow{2}{*}{$\begin{array}{l}\text { SE } \\
\pm\end{array}$} \\
\hline & & 0 & 25 & 50 & 75 & 100 & 125 & \\
\hline \multicolumn{9}{|l|}{ Gas production } \\
\hline GP24 & 62.00 & $63.00^{\mathrm{a}}$ & $59.50^{\mathrm{b}}$ & $60.00^{\mathrm{b}}$ & $54.50^{\mathrm{c}}$ & $52.00^{\mathrm{d}}$ & $53.00^{\mathrm{d}}$ & 0.85 \\
\hline GP48 & 19.50 & $19.00^{\mathrm{a}}$ & $17.50^{\mathrm{c}}$ & $19.00^{\mathrm{a}}$ & $17.50^{\mathrm{c}}$ & $18.50^{\mathrm{b}}$ & $19.50^{\mathrm{a}}$ & 0.50 \\
\hline Total GP & 81.50 & $82.00^{\mathrm{a}}$ & $77.00^{\mathrm{c}}$ & $79.00^{\mathrm{b}}$ & $72.00^{\mathrm{d}}$ & $70.50^{\mathrm{e}}$ & $72.50^{\mathrm{d}}$ & 0.97 \\
\hline GP/hour first 24 & 5.88 & $6.00^{\mathrm{a}}$ & $5.60^{\mathrm{a}}$ & $5.62^{\mathrm{a}}$ & $5.17^{\mathrm{b}}$ & $4.91^{\mathrm{b}}$ & $4.99^{\mathrm{b}}$ & 0.93 \\
\hline $\begin{array}{l}\text { GP/hour second } 24 \\
\text { Rumen parameters }\end{array}$ & 1.85 & $1.81^{\mathrm{a}}$ & $1.65^{\mathrm{c}}$ & $1.78^{\mathrm{b}}$ & $1.66^{\mathrm{c}}$ & $1.74^{\mathrm{b}}$ & $1.84^{\mathrm{a}}$ & 0.91 \\
\hline$\overline{\mathrm{Ph}}$ & 6.53 & 6.64 & 6.60 & 6.53 & 6.53 & 6.64 & 6.60 & 0.01 \\
\hline $\mathrm{NH} 3, \mathrm{mg} / 100 \mathrm{ml}$ & 10.37 & $12.87^{\mathrm{c}}$ & $17.95^{\mathrm{b}}$ & $23.32^{\mathrm{a}}$ & $16.10^{\mathrm{b}}$ & $10.87^{\mathrm{d}}$ & $11.46^{\mathrm{c}}$ & 0.69 \\
\hline TVFA's,meq/100ml & 6.94 & $7.09^{\mathrm{a}}$ & $7.11^{\mathrm{a}}$ & $7.89^{\mathrm{a}}$ & $7.23^{\mathrm{a}}$ & $6.34^{\mathrm{b}}$ & $6.39^{\mathrm{b}}$ & 0.15 \\
\hline MP & 102.15 & $100.91^{\mathrm{e}}$ & $104.97^{\mathrm{d}}$ & $104.75^{\mathrm{d}}$ & $109.37^{\mathrm{c}}$ & $111.96^{\mathrm{b}}$ & $131.28^{\mathrm{a}}$ & 3.33 \\
\hline EMP & 24.77 & $24.16^{\mathrm{e}}$ & $26.26^{\mathrm{d}}$ & $26.10^{\mathrm{d}}$ & $28.71^{\mathrm{c}}$ & $30.27^{\mathrm{b}}$ & $33.14^{\mathrm{a}}$ & 0.86 \\
\hline SCFA & 3.13 & $3.19^{\mathrm{a}}$ & $2.98^{\mathrm{a}}$ & $2.99^{b}$ & $2.75^{\mathrm{b}}$ & $2.61^{\mathrm{c}}$ & $2.65^{\mathrm{c}}$ & 0.04 \\
\hline M E,Mcal/g & 3.73 & 3.75 & 3.69 & 3.69 & 3.62 & 3.58 & 3.65 & 0.01 \\
\hline
\end{tabular}


(Elghandour et al., 2014). The gas production, from any substrate, depends mainly on nutrient availability for rumen microorganisms (Elghandour et al., 2014 and Kholif et al., 2014). Fermentation of dietary carbohydrates to acetate, propionate and butyrate produces gases in the rumen. However, in the current study, standard ration had the same fiber fractions content in different additives. So, it is well clear that the increased gas production (GP) was a result of increased adding of nanocobalt to ration . It is well known that microorganisms has the ability to increase ammonia production in the rumen (Hristov et al., 2013) by increased protein degradation and increased the overall $\mathrm{N}$ excretion by the animal. In these study, the low level of nanocobalt used (25 and 50) improved degradability, gas production and kinetics of fermentation (SCFA, NH3 and MP) than the high level of nanocobalt. Improved ME, MP, and GP 24 were observed with the ration. Rations with high protein content provide ruminal microflora with the essential nutrients for its activity. The highly activity reflected on higher GP, higher microbial protein synthesis, and higher degradability. This can be generalized for the effect of nanocobalt addition on the fermentation activity. Mao et al. (2013) and Elghandour et al. (2015) showed that addition of nanocobalt increased ME. They returned their results to the high activities of microbes in the rumen as a result of produced growth factors for microbial growth and activity in the rumen, and to the ability of nanocobalt to provide conducive anaerobic conditions to microbial growth.

\section{Kinetics of gas production and degradability}

Gas production per gram DM, OM, NDF, ADF, Hemicellulose and Cellulose after 48 hours incubation showed in Table (5). Potential gas production was significantly affected by supplementing ration with cobalt nanoparticles, which significant decrease gas production per gram DM, OM, NDF , $\mathrm{ADF}$ and hemicellulose. On the other hand supplementing ration with cobalt nanoparticles resulted in numerically increase in gas production per gram cellulose. The rate of fermentation varied $(\mathrm{P}<0.05)$ among different additives after 48 hours for nanocobalt had relatively high rate of fermentation in adding $100 \%$ cobalt and $50 \%$ nanocobalt compared to $0 \%$ additive. The rate of gas production was high in cobalt $(100 \%)$ and nanocobalt $(50 \%)$ than the other adding levels.

Table (5) : Gas production ( $\mathrm{ml}$ / 1g DM ) and degradability of DM ,OM, NDF,ADF, hemicellulose and cellulose ( $\mathrm{g} / \mathrm{kg} \mathrm{DM}$ ) after 48 hours incubation.

\begin{tabular}{|c|c|c|c|c|c|c|c|c|}
\hline \multirow[t]{2}{*}{ Item } & \multirow{2}{*}{$\begin{array}{c}\text { Normal } \\
100\end{array}$} & \multicolumn{6}{|c|}{ Nanocobalt ,\% } & \multirow{2}{*}{$\begin{array}{l}\text { SE } \\
\pm\end{array}$} \\
\hline & & 0 & 25 & 50 & 75 & 100 & 125 & \\
\hline \multicolumn{9}{|l|}{ Gas value } \\
\hline$\overline{\text { GPDM48 }}$ & 185.45 & $187.46^{\mathrm{a}}$ & $173.95^{\mathrm{c}}$ & $177.71^{\mathrm{b}}$ & $163.78^{\mathrm{d}}$ & $159.73^{\mathrm{e}}$ & $163.85^{\mathrm{d}}$ & 2.26 \\
\hline GPOM48 & 204.33 & $206.54^{\mathrm{a}}$ & $191.66^{c}$ & $195.80^{b}$ & $180.46^{\mathrm{d}}$ & $175.99^{\mathrm{e}}$ & $180.53^{\mathrm{d}}$ & 2.49 \\
\hline GPNDF48 & 525.05 & $521.40^{\mathrm{a}}$ & $494.71^{c}$ & $504.37^{\mathrm{b}}$ & $463.02^{\mathrm{d}}$ & $452.84^{\mathrm{e}}$ & $464.82^{\mathrm{d}}$ & 6.52 \\
\hline GPADF48 & 1002.33 & $991.89^{\mathrm{a}}$ & $948.85^{\mathrm{c}}$ & $965.34^{\mathrm{b}}$ & $882.63^{\mathrm{d}}$ & $865.71^{\mathrm{e}}$ & $889.22^{\mathrm{d}}$ & 12.73 \\
\hline GPhemi.48 & 1102.64 & $1158.60^{b}$ & $1033.64^{d}$ & $1056.27^{c}$ & $973.99^{\mathrm{e}}$ & $949.52^{f}$ & $1338.40^{\mathrm{a}}$ & 33.33 \\
\hline GPcell.48 & 1290.94 & $774.60^{d}$ & $1222.35^{b}$ & $1243.47^{b}$ & $1136.70^{c}$ & $1115.07^{\mathrm{c}}$ & $1337.61^{\mathrm{a}}$ & 19.69 \\
\hline \multicolumn{9}{|l|}{ Degradability } \\
\hline GPdDM48 & 249.17 & $267.27^{\mathrm{a}}$ & $248.58^{b}$ & $244.38^{c}$ & $228.30^{\mathrm{e}}$ & $247.99^{b}$ & $230.71^{\mathrm{d}}$ & 2.50 \\
\hline GPdOM48 & 495.24 & $494.42^{\mathrm{a}}$ & $477.89^{c}$ & $487.45^{\mathrm{b}}$ & $472.08^{\mathrm{d}}$ & $473.30^{\mathrm{d}}$ & $457.84^{\mathrm{e}}$ & 5.12 \\
\hline GPdNDF48 & 1047.35 & $1332.18^{a}$ & $1265.13^{b}$ & $1134.70^{c}$ & $1029.55^{\mathrm{d}}$ & $976.40 \mathrm{~d}^{\mathrm{e}}$ & $905.98^{f}$ & 27.04 \\
\hline GPdADF48 & 2219.35 & $3163.62^{\mathrm{a}}$ & $2651.64^{b}$ & $2307.58^{c}$ & $2293.53^{d}$ & $1612.63^{\mathrm{e}}$ & $1556.82^{f}$ & 88.53 \\
\hline GPdhemi.48 & 1985.80 & $2435.46^{b}$ & $2444.69^{b}$ & $2252.62^{c}$ & $1880.25^{\mathrm{d}}$ & $2516.69^{a}$ & $1597.10^{\mathrm{e}}$ & 100.51 \\
\hline GPdcell.48 & 3349.98 & $1810.34^{\mathrm{d}}$ & $2312.19^{\mathrm{a}}$ & $2334.16^{\mathrm{a}}$ & $2053.40^{b}$ & $1971.01^{\mathrm{c}}$ & $1414.23^{\mathrm{e}}$ & 167.77 \\
\hline
\end{tabular}

$a, b, c, d$, and $e$ :means in the same rows with different superscripts differed significantly at ( $p<0.05)$.

After 48 hours incubation gas production of dry and organic matter of $0 \%$ without additive and $100 \%$ cobalt were higher values compared to any adding nanocobalt levels . Gas production after 48 hours incubation of hemicellulose of nanocobalt $125 \%$ was the highest value (1338.40) compared to any adding, also gas production after 48 hours incubation of cellulose of nanocobalt was higher values in any adding level especially nanocobalt $125 \%$. The results showed that adding nanocobalt to ration increase growth of cellulolytic bacteria and may be increase fermentation of cellulose. Siegel (1991) suggested that gas production from cereal straws and from different classes of feeds incubated In vitro in buffered rumen fluid was closely related to the production of short chain fatty acid (SCFA) which was based on 
carbohydrate fermentation. Bakker et al. (1995) reported a close association between SCFA and gas production In vitro studies, suggests a potential to make energy available to the ruminants.

After 48 hours incubation gas production degradability dry and organic matter of $100 \%$ cobalt were higher values compared any adding of nanocobalt, but notes that the value of $100 \%$ cobalt approximately equals the value of $50 \%$ nanocobalt. Data showed that gas production degradability after 48 hours incubation hemicellulose of nanocobalt $25 \%$ was the highest value (2444.69) compared any levels of nanocobalt, while degradability cellulose of nanocobalt were high values in $100 \%$ cobalt and $50 \%$ nanocobalt compared to other levels. The results showed that adding of nanocobalt to ration implying that increase growth of cellulolytic bacteria, may be increase fermentation of cellulose and improve degradability of standard ration in the experimental. The higher extent of gas production and rate of degradation of $M$. oleifera suggests that rumen microbes were able to utilize the feed better probably due to a higher content of fermentable nutrients. A higher potential gas production can contribute significantly to energy supply via short chain fatty acid production (Remesy et al., 1995). Digestibility has been reported to be synonymous to In vitro gas production, with a high positive correlation obtained between gas production and dry matter digestibility (Datt and Singh, 1995)

Kaiser et al.(2014) reported that the trace minerals were extremely deficient in all the agricultural wastes in the experiment. This therefore means the ruminant feed may need fortification with minerals in form of either salt lick or diet inclusion. For gas volume and In vitro gas production characteristics, Lina et al. (2009) suggested that gas volume at $24 \mathrm{~h}$ after incubation is an indirect relationship with metabolisable energy in feedstuffs. Gas production can be regarded as an indicator of carbohydrates degradation. Lina et al. (2009) and Rajendran (2013) suggested that gas volume is a good parameter from which to predict digestibility, fermentation end product and microbial protein synthesis of the substrate by rumen microbes in the In vitro studeis. Gas production is basically the result of fermentation of carbohydrates to acetate, propionate and butyrate Sahoo (2014 a) and substantial changes in carbohydrates fractions were reflected by total gas produced (Te-Hsing et al.,2007 ). Gas production from protein fermentation is relatively small as compared to carbohydrate fermentation, while contribution of fat to gas production is negligible, Sahoo (2014 b). Mathematical descriptions of gas production profiles allow analysis of data evaluation of substrates and media related differences and fermentability of soluble and slowly fermentable components of feeds (Newman et al.,2009). Although gas production is a nutritionally wasteful products (Ingale and Chaudhari, 2013), but provides useful basis from which ME, OMD and SCFA may be predicted (Yang and Sun, 2006).

There was a positive correlation between metabolisable energy calculated from In vitro gas production together with $\mathrm{CP}$ and fat content with metabolisable energy value of conventional feeds measured In vivo (Kaiser et al.,2014). The OMD differed significantly with other agricultural wastes. Using the Invitro gas measurement and chemical composition in multiple regression equation (Mishra et al.(2014), and Hahn (1997). Iravani et al.(2014) found a high precision in prediction of In vivo OMD. This group further used a correlative approach to predict the ME content of feed by In vitro gas production measurement and chemical constituents and concluded that the prediction of ME is more accurate when based on gas and chemical constituents only (Lina et al., 2009). Other studeis (Lina et al., 2009, Rajendran et al.,2013 and Koch ,1997) have also reported significant correlation between In vitro gas measurement and In vivo digestibility. Akinfemi et al. (2009) showed that the In vitro gas production techniques can be used to assess the nutritive value of tropical agricultural wastes and to differentiate between their potential digestibility and metabolisable energy contents,also chemical composition and In vitro digestibility are very useful in estimation of OMD, SCFA and ME.

\section{CONCLUSION}

Results revealed that added nanocobalt affect on growth of cellulolytic bacteria and increase degradability of cellulose. In these study adding nanocobalt improved growth of cellulolytic bacteria ,ammonia ,total volatile fatty acids, metabolisable energy and cell wall constituents degradability . Therefore, more investigations are required to see the effect of nanominerals supplementation on the improvement of the In vitro gas production and In vitro degradability . 


\section{REFERENCES}

ATCC. (1992). American Type Culture Collection Catalogue of Bacteria and Bacterophages .18 ${ }^{\text {th }}$ Ed. USA.

Akinfemi, A.; A. O.Adesanya and V. E.Aya (2009). Use of an in vitro gas production technique to evaluate some Nigerian feedstuffs. Amer-Eurasian J. Scientif. Res., 4 (4): 240-245.

AOAC.(1997). Association of Official Analytical Chemists, Official Methods of Analysis, $16^{\text {th }}$ edition, Maryland. USA.

Bakker, H., G.F. Zhou and H. Yang (1995). Mechanically driven disorder and phase transformations in alloys. Prog.Mater. Sci., 39: 159-241.

Barnett,A.J and R.C. Reid (1956). Studies on the production of volatile fatty acids from the grass by rumen liquor in an artificial rumen VFA production from grass. J.Agri.Sci.,48:131-161.

Blummel, M. and E. R. Orskov (1993). Comparison of In vitro gas production and nylon bag degradability of roughages in predicting of food intake in cattle. Anim. Feed Sci. Technol.,40:109119.

Blummel, M., H. Steingas and K.Becker (1997). The relationship between in vitro gas production, in vitro microbial biomass yield and $\mathrm{N}$ incorporation and its implications for the prediction of voluntary feed intake of roughages. British J. Nutr., 77: 911-921.

Bunglavan, S.J., A.K. Garg, R.S. Dass and S.Shrivastava (2014). Use of nanoparticles as feed additives to improve digestion and absorption in livestock. Livestock Research International. 2 : Issue $3: 36-47$.

Callaway E.S. and S.A. Martin (1997). Effects of a Saccharomyces cerevisiae culture on ruminal bacteria that utilize lactate and digest cellulose. J Dairy Sci.,80:2035-2044.

Colombatto D., F.L. Moulda, M.K. Bhat and E.Owen (2007). Influence of exogenous fibrolytic enzyme level and incubation $\mathrm{pH}$ on the in vitro ruminal fermentation of alfalfa stems. Anim. Feed Sci. Technol., 137, 150-162.

Cone J.W., A.H.Van Gelder, H. Bachmann and V.A. Hindle (2002).Comparison of organic matter degradation in several feedstuffs in the rumen as determined with the nylon bag and gas production techniques. Anim. Feed Sci. Technol., 96, 55-57.

Cone J.W., A.H.Van Gelder, I.A.Soliman, H.De Visser and A.M. Van Vuuren (1999). Different techniques to study rumen fermentation characteristics of maturing grass and grass silage. J. Dairy Sci., 82, 957-966.

Cone J.W., A.H.Van Gelder and H. Valk (1998). Prediction of nylon bag degradation characteristics of grass samples with the gas production technique. J. Sci. Food Agric., 77, 421-426.

Datt, C. and G.P. Singh (1995). Effect of protein supplementation on in vitro digestibility and gas production of wheat straw. Indian J. Dairy Sci., 48: 357-361.

Duncan D.B. (1955). Multiple range and multiple F-test. Biometrics, 11, 1-42.

Elghandour M.M.Y., A.Z.M. Salem, J.S. Martínez Castañeda, L.M. Camacho, A.E. Kholif and J.C. Vázquez Chagoyán (2015). Direct-fed microbes: a tool for improving the utilization of low quality roughages in ruminants. J. Integr. Agr. ,14 (3):526-533.

Elghandour M.M.Y., J.C. Vázquez Chagoyán, A.Z.M. Salem, A.E. Kholif, J.S. Martínez Castañeda, L.M. Camacho and M.A. Cerrillo-Soto (2014). Effects of Saccharomyces cerevisiae at direct addition or pre-incubation on In vitro gas production kinetics and degradability of four fibrous feeds. Ital. J.Anim. Sci. 13:295-301.

Gall, L. S., S. E. Smith, D. E. Becker, C. N. Stark and J. K. Loosli (1949) . Rumen bacteria in cobaltdeficient sheep. Science. 109:468-469.

Gall, L.S.; W. Burroughs; P. Gerlaugh and B.H. Edginton (1945). Special methods for rumen bacterial studies in the field. J. Anim. Sci., 8: 433-436. 
Getachew, G.;H. P. S. Makkar and K. Becker. (2002). Tropical browses: Contents of phenolics compounds, In vitro gas production and stoichiometric relationship between short chain fatty acid and In vitro gas production. J. Agric.Sci., 139: 341-352.

Hahn, H. (1997). Unique features and properties of nanostructured materials. Nanostruct. Mater., 9: 3-12.

Hansen,H.H.; H.M.Ebied and N.ElBordeny (2016). In vitro evaluation of Moringa seeds cake as a feedstuff for dairy animal (under publication )

Hayashi H.; M. Takehara; T.Hattori; T.Kimura; S.Karita; K.Sakka and K.Ohmiya. (1999). Nucleotide sequences of two contiguous and highly homologous xylanase genes $x y n A$ and $x y n B$ and characterization of XynA from Clostridium thermocellum. Appl Microbiol Biotechnol. , 51:348-357.

Hristov, A.N., J. Oh, J.L. Firkins, J. Dijkstra, E. Kebreab, G. Waghorn, H.P. Makkar, A.T. Adesogan, W. Yang and C. Lee (2013). Special topics: mitigation of methane and nitrous oxide emissions from animal operations: I. A review of enteric methane mitigation options. J. Anim. Sci., 91:5045-5069.

Ingale, A.G. and A.N. Chaudhari (2013). Biogenic synthesis of nanoparticles and potential applications: An eco-friendly approach. J. Nanomed. Nanotechol., 4: 165.

Iravani, S., H.Korbekandi, S.V. Mirmohammadi and B.Zolfaghari (2014). Synthesis of silver nanoparticles:Chemical, physical and biological methods. Res. Pharm.Sci., 9(6): 385-406.

Kaiser, D.L., S.Standridge, L.Friedersdorf, C. L.Geraci, F. Kronz, M. A.Meador and D. M. Stepp (2014). National Nanotechnology Initiative Strategic Plan by National Science and Technology Council Committee on Technology. Subcommitte on Nanoscale Science, Engineering and Technology.pp 30.

Khazaal, K., X. Markantonatos, A. Nastis and E. R. Orskov (1993). Changes with maturity in fiber composition and levels of extractable polyphenols in Greek browse: effect on vitro gas production and in sacco dry matter degradation. J. Sci. Food Agric. 63:237-244.

Kholif A.E., H.M. Khattab, A.A. El-Shewy, A.Z.M. Salem, A.M. Kholif, M.M. El-Sayed, H.M. Gado and M.D. Mariezcurrena ( 2014). Nutrient digestibility, ruminal fermentation activities, serum parameters and milk production and composition of lactating goats fed diets containing rice straw treated with with Pleurotus ostreatus. Asian-Australas J.Anim.Sci.,27(3):357-364.

Koch, C.C. (1997). Synthesis of nanostructured materials by mechanical milling: Problems and opportunities. Nanostruct. Mater., 9: 13-22.

Koutzarova, T.;S. Kolev; C. Ghelev; D. Paneva and I. Nedkov (2006). Microstructural study and size control of iron oxide nanoparticles produced by microemulsion technique. .Phys. Stat. Sol., 3: 13021307.

Krishnamoorthy, H., H.Steingass and K.H. Menke (1991).Preliminary observations on the relationships between gas production and microbial protein synthesis in vitro. Arch. Tierernahr., 41, 521-526.

Krishnamoorthy, U., K.C. Singh and M.M. Kailas (2005). Evaluation of roughages for rumen microbial biomass synthesis. Indian Vet. J., 82(4): 453-454.

Lina, T., J. Jianyang, Z. Fenghua, R. Huiying and L.Wenli (2009). Effect of nano-zinc oxide on the production and dressing performance of broiler. Chinese Agricultural Science Bulletin, 2: 003.

Manigandan, R.; K. Giribabu; R. Suresh; L. Vijayalakshmi, A. Stephen and V. Narayanan (2013). Cobalt Oxide Nanoparticles: Characterization and its Electrocatalytic Activity towards Nitrobenzene. Chem. Sci. Trans., 2(S1): S47-S50.

Mao, H.L., J.K. Wang, J.X. Liu and I.Yoon ( 2013). Effects of Saccharomyces Cerevisiae fermentation product on In vitro fermentation and microbial communities of low-quality forages and mixed diets. J. Anim. Sci., 91:3291-3298.

Menke, H.H. and H. Steingass (1988): Estimation of the energetic feed value obtained from chemical analysis and In vitro gas production using rumen fluid. Anim. Res. Dev., 28: 7-55.

Mishra, A., R.K. Swain, S.K. Mishra, N. Panda and K. Sethy (2014) .Growth performance and serum biochemical parameters as affected by nano zinc supplementation in layer chicks. Indian J. Anim. Nutr., 31(4): 384-388. 
Mohand-Oussaid, O; S. Payot; E.Guedon; E.Gelhaye; A.Youyou and H.Petitdemange (1999) The extracellular xylan degradative system in Clostridium cellulolyticum cultivated on xylan: evidence for cell-free cellulosome production. J. Bacteriol. ,181:4035-4040.

Moir, R.J. (1951). The seasonal variation in the ruminal micro organisms of grazing sheep. Australian J. Agric. Res., 2: 322-331.

NRC (1985). National Research Council, Nutrition requirements of goats .6 ${ }^{\text {th }}$ revised Ed. National Academy Press. Washington. D.C., USA.

Newman, M.D., M. Stotland and J.I. Ellis (2009) The safety of nanosized particles in titanium dioxide and zinc-oxide based sunscreens. J. Am. Acad. Dermatol., 61(4): 685-692.

Orskov, E.R. (1989). Recent advances in evaluation of roughages as feeds for ruminants. In: Farell D.J. (ed):Advances in animal nutrition. University of New England Printery, Armidale, 102-108.

Partha, S. S., D. Rajendran, S. B. N. Rao and G. Dominic (2015). Preparation and effects of nano mineral particle feeding in livestock. A review, Veterinary World 8(7): 888-891.

Pounden, W.D. and J.W. Hibs (1948). The influence of the ratio of grain to hay in the ration of dairy calves in certain rumen micoorganisms. J. Dairy Sci., 31: 1051-1057.

Rajendran, D.(2013). Application of nano minerals in animal production system. Res. J. Biotechnol.,8(3): $1-3$.

Rajendran, D., A. Thulasi, S.Jash, S.Selvaraju and S.B.N. Rao (2013). Synthesis and application of nano mineralsin livestock industry. In: Sampath, K.T., Ghosh, J.,Bhatta, R., editors. Animal Nutrition and Reproductive Physiology (Recent Concepts). Satish Serial Publishing House, Delhi, p517-530.

Remesy, C. ; C. Demigne and C. Morand (1995). Metabolism of short-chain fatty acids in the liver. In: Cummings, J. H., Rombeau, J. L., Sakata, T., (eds), Physiological and clinical aspects of short- chain fatty acids, (Cambridge University Press, Cambridge), p. 171-190

Roger, Koukiekolo ; Hee-Yean Cho; Akihiko Kosugi ;Masayuki Inui ; Hideaki Yukawa and Roy H. Doi (2005). Degradation of corn fiber by Clostridium cellulovorans cellulases and hemicellulases and contribution of scaffolding protein. Appl. Environ. Microbiol.71:3504-3511.

SAS. (1998). Statistical analysis system. User's Guide Inst., Inc.Cary, NC,USA.

Sahoo, A., R.K. Swain and S.K. Mishra (2014b). Effect of inorganic, organic and nano zinc supplemented diets on bioavailability and immunity status of broilers. Int. J. Adv.Res., 2(11): 828-837.

Sahoo, A., R.K. Swain , S.K. Mishra and B.Jena (2014a) .Serum biochemical indices of broiler birds fed on inorganic, organic and nano zinc supplemented diets. Int. J. Recent Sci. Res., 5(11): 2078-2081.

Scholljegerdes ,E. J., W. J. Hill, H. T. Purvis, L. A. Voigt and C. S. Schauer (2010). Effects of Supplemental Cobalt on Nutrient Digestion and Nitrogen Balance in Lambs Fed Forage-based Diets. Sheep \& Goat Research Journal, 25:74-77

Siegel, R.W. (1991). Processing of Metals and Alloys. In R.W. Cahn(ed). Materials Science and Technology.15:p.583.

Sleat, R., R. A. Mah and R.Robinson (1984). Isolation and characterization of an anaerobic, cellulolytic bacterium, Clostridium cellulovorans sp. Appl. Environ. Microbiol., 48:88-93 .

Sutton, A. L. and J. M. Elliot ( 1972). Effect of ratio of roughage to concentrate and level of feed intake on ovine ruminal vitamin B12 production. J. Nutr. 102:1341-1346.

Szumacher-Strabel, M.; A. Potkanski; J .Kowalczyk; A. Cieslak; M. Czauderna; M .Gubala and P. Jedroszkowiak (2002). The influence of supplemental fat on rumen volatile fatty acid profile, ammonia and $\mathrm{pH}$ level in sheep fed a standard diet. Journal of Animal and Feed Sciences,11(4):577587.

Te-Hsing, W., T. Yi-Der and S.Lie-Hang (2007). The novel methods for preparing antibacterial fabric composites containing nano-material. Solid State Phenom., 124(12):1241-1244.

Tiffany, M.E., V. Fellner and J.W. Spears (2006). Influence of cobalt concentration on vitamin B12 production and fermentation of mixed ruminal microorganisms grown in continuous culture flowthrough fermentors. J. Anim. Sci., 84: 635-640. 
Tiffany, M. E., J. W. Spears, L. Xi, and F. R. Valdez (2002). Effects of dietarycobalt source and oncentration on performance, vitamin B12 status, and ruminal and plasma metabolites in growing and finishing steers. J. Anim. Sci. 80 (Suppl. 1):183.(Abstr.)

Valentin S.F., P.E.V.Williams, J.M.Forbes and D. Sauvant (1999). Comparison of the In vitro gas production technique and the nylon bag degradability technique to measure short and long term processes of degradation of maize silage in dairy cows. Anim. Feed Sci. Technol.,78: 81-99.

Van Soest, P.V., J.B. Robertson, and B.A. Lewis (1991). Methods for dietary fiber, neutral detergent fiber and non starch polysaccharides in relation to animal nutrition. J. Dairy Sci., 74: 3583-3597

Weiner, E.C., M.W. Brechbiel, S.H.Brother, R.L.Magin, O.A. Gansow and D.A. Tomalia (1994).Dendrimer-based metal chelates : a new class of magnetic resonance imaging cantrast agents.Magn Reson Med.,31:1-8

Yang, Z.P. and L.P. Sun (2006). Effects of nanometre $\mathrm{ZnO}$ on growth performance of early weaned piglets. J. Shanxi Agric. Sci., 3: 024.

تقييم إضافة النانوكوبلت لعلائق المجترات باستخدام أسلوب إنتاج الغازمعمليا

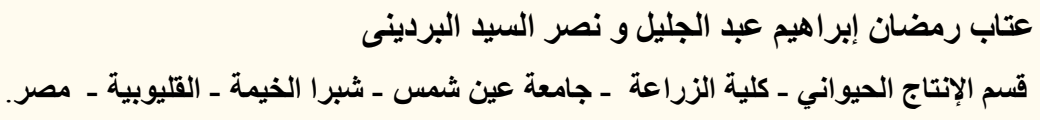

يهدف هذا البحث الي تقييم الإضافات من النانوكوبالت على نمو البكتيريا المحلة للسيليلولوز، هضم المادة الجافة والسليلوز

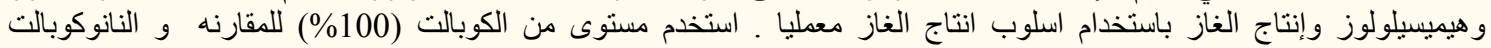

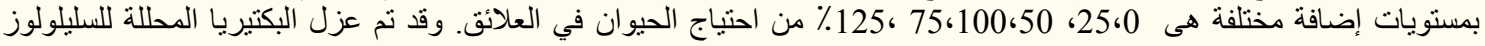
Cellulomonas cellulasea, Acetobacter xylinum, Thermonospora fusca, Ruminococcus albus , Bacillus sp.,

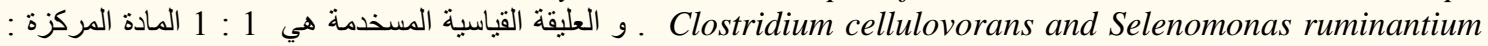
دريس البرسيم و التحضين لمدة 48 ساعة .

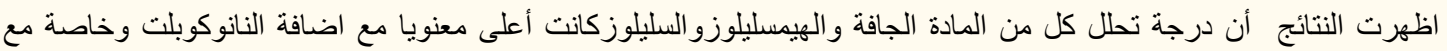

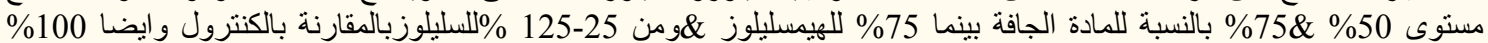
كوبلت عادى.

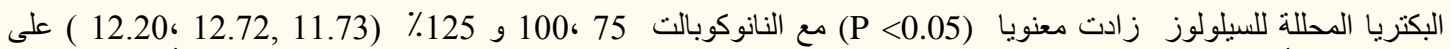

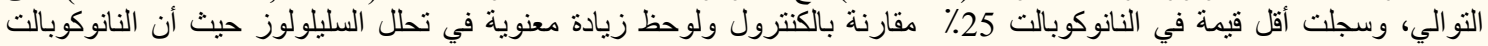

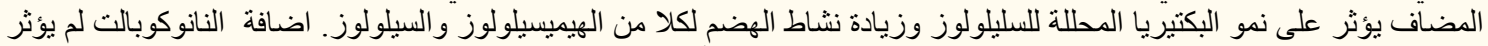

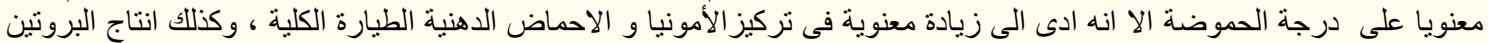
الميكروبى . معنى على

إنتاج الغاز كان أعلى معنويا في عليقة الكنترول (0) (2) إيضا النانوكوبالت (50\%) مقارنة بباقى المستويات الأخرى. إنتاج الغاز الناتج

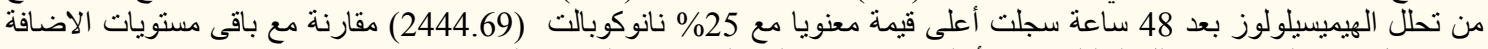

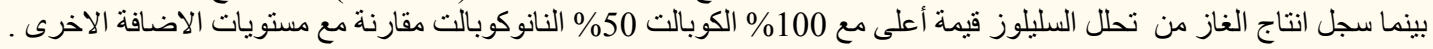

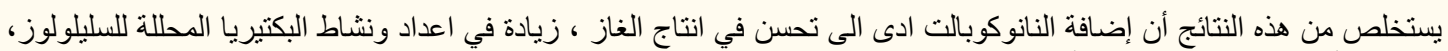

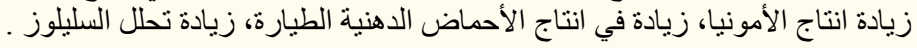

